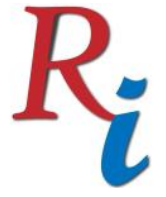

Asia Proceedings of Social Sciences

(APSS)

www.readersinsight.net/APSS

\title{
Equity Market Indicators as Drivers of Foreign Portfolio Investment in Pakistan
}

\section{Zahirullah*}

PhD Scholar, Institute of Management Studies, University of Peshawar Pakistan

\section{Mumtaz Hussian Shah}

Assistant Professor, Institute of Management Studies, University of Peshawar Pakistan

*Corrosponding author's Email: zaheer1854@gmail.com 


\section{Research High Iight s}

The study is about the factors responsible of attracting foreign portfolio investment (FPI) to Pakistan stock exchange (PSX). In this study the stock market factors of PSX have been explored to determine their short term and as well as long term association with the equity market indicators of PSX.

\section{Graphical A bstract}

The following diagram shows the graphical sketch of the study variables.

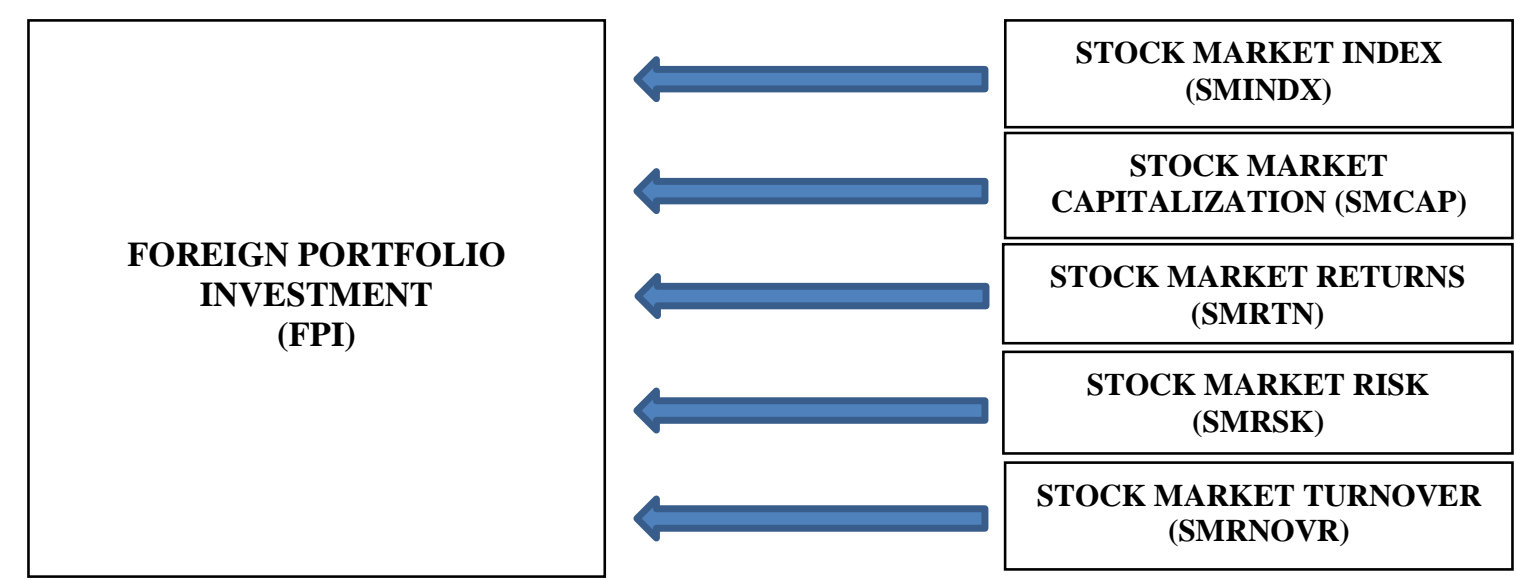

\section{Research Objectives}

There are two types of foreign investment. One is foreign direct investment (FDI) and another is foreign portfolio investment (FPI). In FDI investors have direct control over management whereas in FPI, investors do not have control over management as it is investment in the stock market securities of a country. FPI has short term nature and is more volatile in nature as compared to FDI ((UNCTD, 1999); Khan, 1996)).

The main objectives of the study are:

- To identify the key equity market factors having significant relationship with FPI in Pakistan

- To explore and analyze the relationship between equity market factors and FPI in Pakistan

- To guide the policy makers and investors to get maximum out of FPI 


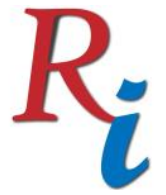

\section{Asia Proceedings of Social Sciences \\ (APSS) \\ www.readersinsight.net/APSS}

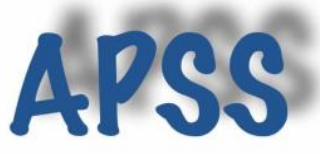

The study will contribute to the academia as this area needed to be explored and this will work as a reference material for the future researchers. Secondly this study will provide guidance to the policy maker to initiate steps for making FPI more beneficial for both government and investors.

\section{Methodology}

The methodology includes the data collection, variables included and the econometric modeling techniques employed. Ten years quarterly data from July 2007 to June 2008 is extracted from the website of PSX and state bank of Pakistan (SBP). The variables include the dependent variable net foreign portfolio investment (NFPI) which is the difference between the securities sold and securities bought. The data for this variable is taken from SBP. The independent variables include stock market index showing the stock market performance, market capitalization, risk, return and the turnover value traded. Data for these variables is taken from PSX. Their relationship and coding scheme can be seen in the graphical abstract. The cumulative hypothesis devised from the literature to achieve the aims and objectives of the study is:

H1: Stock market factors (stock market index, market capitalization, return and the turnover value traded) have positive and stock market risk has significant negative relationship with NFPI

H0: Stock market factors (stock market index, market capitalization, return and the turnover value traded) have no positive and stock market risk has no significant negative relationship with NFPI

To establish long term relationship between the dependent and independent variables, cointegration technique is employed ((Engle and Granger (1987), Johansen (1988), Anayochukwu (2012)). Co-integration technique is the most suitable and widely accepted (Gujrati, 2004). For co-integration, the stationarity of the data series is checked by using unit roots Augmented Dickey-Fuller tests Dickey (1976) and Fuller (1976). After establishing long term relationship, error correction model (ECM) was employed in order to analyze the short term relationship. Further in last, to quantify the magnitude of this relationship and showing the cause and effect between the said set of variables, regression analysis has been taken place by employing the multiple regression technique through ordinary least square method (OLS).

\section{Results}




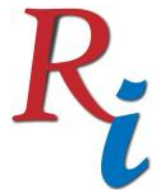

\section{Asia Proceedings of Social Sciences \\ (APSS) \\ www.readersinsight.net/APSS}

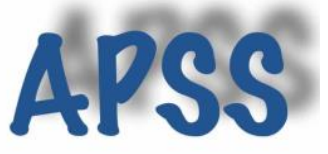

Before going for Johansen co-integration, it was found that all the data series were not stationary at level, so, after taking they become stationary at level. The Johansen co-integration shows that three equations are co-integrated, so we move up for the employment of ECM which is the prerequisite for ECM. Short term relationship was also found between three variables as well.

The regression analysis shows that market index and market capitalization have positive and significant impact on NFPI. Market returns and turnover have positive and slightly significant impact on NFPI. Market risk is slightly significant and negative association with NFPI.

\section{Findings}

It is found that stock market factors have long term as well as short term relationship with NFPI. In short term, the past values have negative effect on the current values of the variables. The regression results show that with one unit change in NFPI, the market capitalization change by 2.2 units (Million USD). Similarly for market index, market turnover and market returns; for one unit change in NFPI, they change by0 .38, 0.94 and 0.93 units respectively. For market risk this change is negative 7.63 units. Most of the results comply with ((Halale, (2014); Warther (1995); Adabag and Ornelas (2004)).

In summarized form it is found that while investing in PSX, foreign investor cannot ignore the stock market factors. Foreign investors should consider these factors while making investment decision regarding PSX. Policy makers can work more on giving incentives to foreign investors to diversify their portfolio risk and making foreign investment more beneficial.

\section{References}

Adabag, C., \& Ornelas, J. R. H. (2004). Behaviour and effects of foreign investors on Istanbul Stock Exchange.

Anayochukwu, B. O. (2012). The Impact of stock Market Returns on Foreign Portfolio Investments in Nigeria. IOSR Journal of Business and Management, 2(4), 1019.

Engle, R. F. \& Granger, C. W. J, 1987. 'Co-integration and error correction': Representation, estimation, and testing. Econometrica, 55, 251-276. 


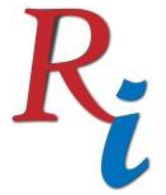

\section{Asia Proceedings of Social Sciences}

(APSS)

www.readersinsight.net/APSS

Halale, M. S. (2014). Influence Of Foreign Portfolio Investment On Stock Market Indicators. Journal Impact Factor, 5(10), 01-11.

Johansen, S., 1988. Statistical analysis of co-integration vectors. Journal of Economic Dynamics and Control, 12, 231-254.

Khan, A. H., \& Khilji, N. M. (1997). Foreign Direct Investment in Pakistan: Policies and Trends [with Comments]. The Pakistan Development Review, 959-985.

UNCTAD/GDS/DFSB/5 "Comprehensive Study of the Interrelationship between Foreign Direct Investment (FDI) and Foreign Portfolio Investment (FPI)", A staff paper prepared by the UNCTAD secretariat, 1-46

Warther, V. A. (1995). Aggregate mutual fund flows and security returns. Journal of financial economics, 39(2-3), 209-235. 